\title{
BIOGENIC SYNTHESIS OF SILVER NANOPARTICLES USING MANILKARA HEXANDRA (ROXB.) DUBARD STEM BARK EXTRACT AND IT'S PHYSICAL, CHEMICAL CHARACTERIZATION AND PHARMACEUTICAL EVALUATION
}

\section{A. ANTONY LAWRENCE, J. THOMAS JOSEPH PRAKASH ${ }^{*}$}

PG and Research Department of Physics, Government Arts College, (Affiliated to Bharathidasan University), Trichy 620022 Email: armyjpr1@yahoo.co.in

Received: 16 Dec 2018, Revised and Accepted: 05 Mar 2019

\section{ABSTRACT}

Objective: The present study was to synthesize nanoparticles using Manilkara hexandra stem bark extract its characterization and evaluating it by an antimicrobial and antioxidant assay.

Methods: Manilkara hexandra stem bark silver nanoparticles (MHSB-AgNPs) was done by mixing silver nitrate (1 mmol) and aqueous stem bark extract and it was analyzed by UV-Visible spectroscopy, X-ray diffraction (XRD), Fourier transform infrared spectroscopy (FTIR), dynamic light scattering (DLS), Zeta potential, Field Emission Scanning Electron Microscopy (FE-SEM), Energy Dispersive Spectroscopy (EDAX), Thermogravimetry/Differential Thermal Analysis (TG/DTA) and Differential scanning calorimetry (DSC). The antibacterial assay was done by a well diffusion method and also examined for antifungal assay was done by disk diffusion method and antioxidant potential Diphenyl-1-picryl hydrazyl (DPPH method)

Results: Manilkara hexandra stem bark silver nanoparticles (MHSB-AgNPs) is characterized by various techniques such as UV-visible absorption spectrum ranges from $430 \mathrm{~nm}$ to $440 \mathrm{~nm}$ indicate silver nanoparticles. The Fourier Transform Infrared Spectroscopy consists of biomolecules acts as capping agent to form silver nanoparticles. Field Emission Scanning Electron Microscopy shows particle size ranges from $15 \mathrm{~nm}$ to $50 \mathrm{~nm}$. Energy Dispersive Spectroscopy shows the presence of Silver. X-ray Diffraction corresponds to face-centered lattice planes (111), (200), (220) and (311). Dynamic Light Scattering show the range of $68 \mathrm{~nm}$ and Zeta potential show the negative value of-17 nm which has high stability. Silver nanoparticles is also examined by Thermogravimetry/Differential Thermal Analysis (TG/DTA) and Differential scanning calorimetry (DSC) this project the thermal stability of the nanoparticles. The aqueous stem bark is also examined by UV-visible absorption spectrum, Fourier Transform Infrared Spectroscopy (FTIR), and Gas Chromatography-Mass Spectrometry (GCMS). In GCMS 20 compounds were identified. Silver nanoparticles show high zone of inhibition in antimicrobial assays and act as a good antioxidant agent.

Conclusion: It is eco-friendly, non-toxic, and it's easy to synthesis and it shows good result in an antimicrobial and antioxidant assay can be applied in a pharmaceutical application.

Keywords: Manilkara hexandra, Stem bark extract, Silver nanoparticles, Antibacterial assays, Antioxidant assay

(C) 2019 The Authors. Published by Innovare Academic Sciences Pvt Ltd. This is an open-access article under the CC BY license (http://creativecommons.org/licenses/by/4.0/) DOI: http://dx.doi.org/10.22159/ijap.2019v11i3.31403

\section{INTRODUCTION}

Indian tradition uses the medicinal plant as the predecessor for the development of the drug from the plant and is also used in modern days. It is effective because of the bio-compounds present in it has no side effects and costs less [1]. The mixture of traditional and modern ideas produces a new source of active compounds which can be used as medicine with low side effects [2]. Among various metals ( $\mathrm{Ag}, \mathrm{Au}$, $\mathrm{Pt}, \mathrm{Pd}, \mathrm{Cu}$, etc.) AgNPs having intense effect for research in recent years is due to its properties [3]. AgNPs can be synthesized by physical and chemical methods, but our aim is to develop an environmental friendly method [4]. Green synthesis is the best method its effective, novel method $[5,6]$. Silver nanoparticles in a biological approach involve microorganisms, plants, and viruses (or) their biomolecules [7]. Silver nanoparticles are currently applied in medicine, consumer products, even in surgical blades, catheters, and food packing [8]. The colloidal silver nanoparticles can be used as a wound dressing material, tooth cement, replacement for bones, water purifier and antimicrobial agent [9]. The botanical name of the plant is Manilkara hexandra (Roxb.) Dubard belong to Sapotaceae family, Genus-Manilkara, Species-Manilkara hexandra, in Tamil it is called as Ulakkaippaalai or Kanuppaalai. The various parts of Manilkara hexandra contain medicinal values such as astringent, colic, dyspepsia, anorexia, leprosy, anthelmintic, refrigerant, hallucination, loss of consciousness, fermentation process etc. [10].

Our aim was to develop silver nanoparticles using the stem bark of Manilkara hexandra (Roxb.) Dubard and it is novel work. In our work, we identify biocompounds first by phytochemical screening and GC-MS for aqueous stem bark extract and then we use centrifuge techniques to collect the silver nanoparticles. It has been characterized by various studies such as UV-vis absorption, FT-IR, FE-SEM, EDAX, XRD, DLS, Zeta potential, TG/DTA, DSC. The silver nanoparticles are also tested by antimicrobial assays and free radical scavenging activity (DPPH method).

\section{MATERIAL AND METHODS}

\section{Materials}

All chemicals (AR grade) were purchased from Sigma-Aldrich Chemicals, India. The stem bark of Manilkara hexandra (Roxb.) Dubard was collected from Jayankondam at Ariyalur District, Tamil Nadu in India. The plant was identified in the Rapinet herbarium, in St. Joseph College, Trichy. The voucher sample was preserved (Voucher No: AAL 001) shown in fig. 1.

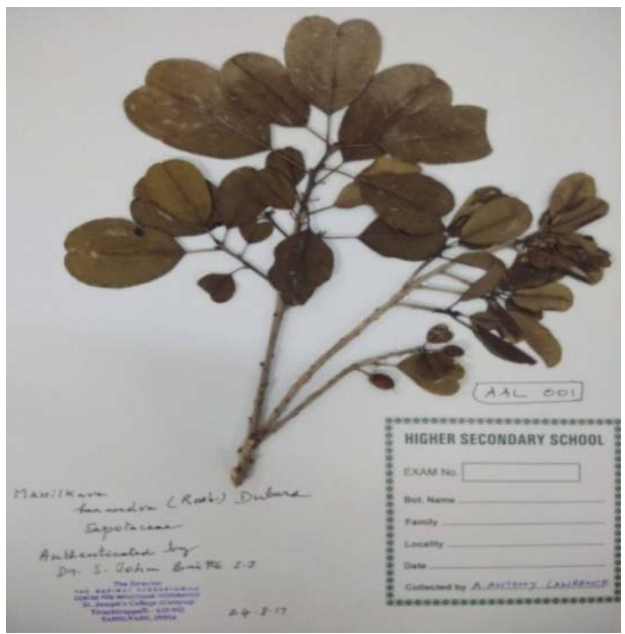

Fig. 1: Manilkara hexandra (Roxb.) dubard identified in rapinet herbarium 


\section{Mechanism of AgNPs formation}

The bioactive compounds present in the extract react with $\mathrm{AgNO}_{3}$ to form AgNPs [11]. The biosynthesis mechanism of nanoparticles is explained below.

$$
\mathrm{Ag}^{+} \mathrm{NO}_{3}{ }^{-}+\text {Stem bark extract } \rightarrow \text { Ag }{ }^{\circ} \mathrm{NPs}+\text { by-products }
$$

The bioactive compounds present in stem bark extract act as reducing agent. The reduction process is mainly due to flavonoids which act as a strong reducing agent. The biological compounds act as capping, reducing agent and is a major cause for the stability of compounds [12].

\section{Synthesis of silver nanoparticles}

The stem bark of Manilkara hexandra was washed in tap water and again washed with distilled water, then allowed to air-dry under the shade for two weeks. After it was crushed into a fine powder using pestle mortar $10 \mathrm{~g}$ of Manilkara hexandra stem bark powder was soaked in $100 \mathrm{ml}$ of double-distilled water for $30 \mathrm{~min}$. This mixture is then heated at $60{ }^{\circ} \mathrm{C}$ for $20 \mathrm{~min}$, after which it is cooled to room temperature. Finally, the filtrate is stored in the refrigerator for further investigations. Chemical compounds were analyzed by using phytochemical screening [13]. Six ml of stem bark was added to the $120 \mathrm{ml}$ of the $10^{-3} \mathrm{M}$ silver nitrate $\left(\mathrm{AgNO}_{3}\right)$ solution. When the reaction started, we observe the change in color from yellow to dark brown. These silver nanoparticles were separated using a highspeed centrifuge (Remi RM-12C) at 12,000 rpm for $15 \mathrm{~min}$. After separation, nanoparticles is purified with alcohol and dried in a hot air oven at $200{ }^{\circ} \mathrm{C}$ for $2 \mathrm{~h}$. The product is then powdered and stored in a properly labelled container for further studies. The characterization instruments and its uses are listed in table 1.

Table 1: Instrument model and its application

\begin{tabular}{ll}
\hline Instrument and model & Application \\
\hline UV-visible spectroscopy (U-2910 Hitachi) & Optical studies \\
FT-IR (IRAffinity-1S Shimadzu) & Functional group identification \\
FE-SEM (JEOL JSM-6701F) & Surface morphology studies \\
EDAX (INCA Penta FETX3 OXFORD) & Elemental analysis \\
XRD (X'Pert Pro-P Analytic) & Lattice parameter \\
DLS, Zeta Potential (Malvern Zetasizer, Nano ZS90) & Particle size, stability \\
GC-MS (SHIMADZU QP 2010Plus) & Identify chemical compounds \\
TG/DTA (DT Q600 V20.9 Build 20) & Thermal Analysis \\
DSC (NETZSCH DSC 214 Polyma) & Characteristic properties \\
\hline
\end{tabular}

\section{Antibacterial assay}

The antibacterial activity of the stem bark extract, Manilkara hexandra stem bark silver nanoparticles (MHSB-AgNPs), silver nitrate $\left(\mathrm{AgNO}_{3}\right)$ solution, and standard were determined by the well diffusion method against various bacteria, such as Klebsiella pneumonia, Staphylococcus aureus, Escherichia coli, Pseudomonas aeruginosa and Streptococcus pneumonia on Muller Hinton agar according to the Clinical and Laboratory Standards Institute (CLSI) [14]. The testing sample $(75 \mu \mathrm{l} / \mathrm{ml})$ is loaded with $6 \mathrm{~mm}$ of an antibiotic disc and compared with Amoxicillin as standard.

\section{Antifungal assay}

The antifungal activity of stem bark extract, Manilkara hexandra stem bark silver nanoparticles (MHSB-AgNPs), silver nitrate $\left(\mathrm{AgNO}_{3}\right)$ solution, and standard were determined by disk diffusion method against two fungal stains such as Candida albicans and Aspergillus niger on Sabouraud's dextrose agar [15]. The testing sample $(10 \mu \mathrm{l} / \mathrm{ml})$ is loaded in $6 \mathrm{~mm}$ of an antifungal disc and is compared with Fluconazole as standard.

\section{Free radical scavenging activity on DPPH method (in vitro)}

2,2-diphenyl-1-picrylhydrazyl (DPPH) is used for examining free radical scavenging activity. DPPH radicals $(0.2 \mathrm{mmol})$ are prepared in methanol solution. Manilkara hexandra stem bark silver nanoparticles (MHSB-AgNPs) concentration varied from 20$100 \mu \mathrm{g} / \mathrm{ml}$ with water mixed with one $\mathrm{ml}$ of prepared 2,2-diphenyl-1- picrylhydrazyl (DPPH) solution in a test tube. It is shaken vigorously and kept in a dark room for 30 min after absorbance is measured. Similarly, ascorbic acid is used as a standard to compare the silver nanoparticles. After measuring the IC 50 value is calculated [16].

The scavenging ability is calculated using formula.

$$
\% \text { of inhibition }=100 \times((\mathrm{A}-\mathrm{B}) / \mathrm{A})
$$

Where I (\%) is inhibition percentage

A- Absorbance of control reaction

B- Sample absorbance of test compound.

\section{RESULTS}

\section{Phytochemical screening and GC-MS analysis}

The aqueous stem bark of Manilkara hexandra was screened and confirms the presence of alkaloids, anthocyanin, anthroquinone, carbohydrates, coumarins, flavonoids, glycosides, gumandmusilage, phlobatannin, protein, quinine, resin, saponin, steroids, tannin, terpenoids, xanthoprotein and absence of amino acid, emodins, fixed oils and fats. The GC-MS spectrum reveals 20 compounds in which two are major compounds. First major compounds are Phthalic acid, di-(1-hexen-5-yl) ester at a retention time (15.567) and second major compounds are 5-Methyl-1-heptanol at a retention time (16.599) shown in fig. 2 and table 2.

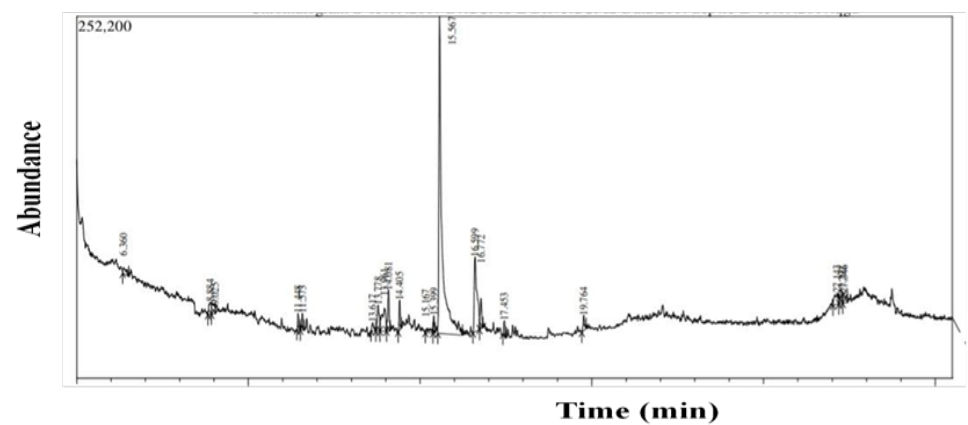

Fig. 2: Gas chromatography-mass spectrometry (GC-MS) analysis of Manilkara hexandra aqueous stem bark extract 

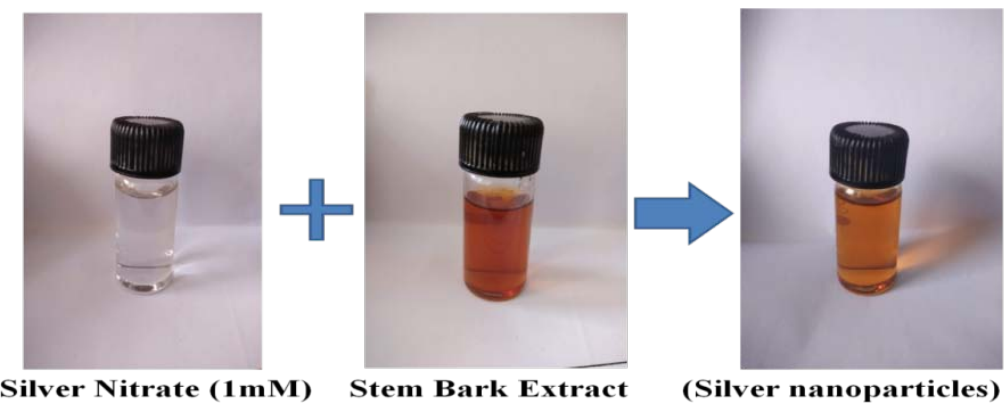

MHSB-AgNPs

Fig. 3: Silver nitrate solution mixed with stem bark extract gives Manilkara hexandra stem bark silver nanoparticles (MHSB-AgNPs)

\section{Synthesis and characterization of silver nanoparticles}

The primary identification of silver nanoparticle is the change of color from yellow to dark brown and is shown in fig. 3.

The Manilkara hexandra stem bark extract and MHSB-AgNPs were first determined by UV-visible spectrum wavelength ranging from
300-1100 $\mathrm{nm}$. Where double distilled water was used as reference [17]. The UV-visible absorption spectrum of bio-synthesized Manilkara hexandra stem bark silver nanoparticles (MHSB-AgNPs) is analyzed at various intervals of time. It has an optical absorption range from $430-440 \mathrm{~nm}$ and for the stem bark extract, it is $311 \mathrm{~nm}$ shown in fig. $4 \mathrm{a}$ and fig. $4 \mathrm{~b}$

a
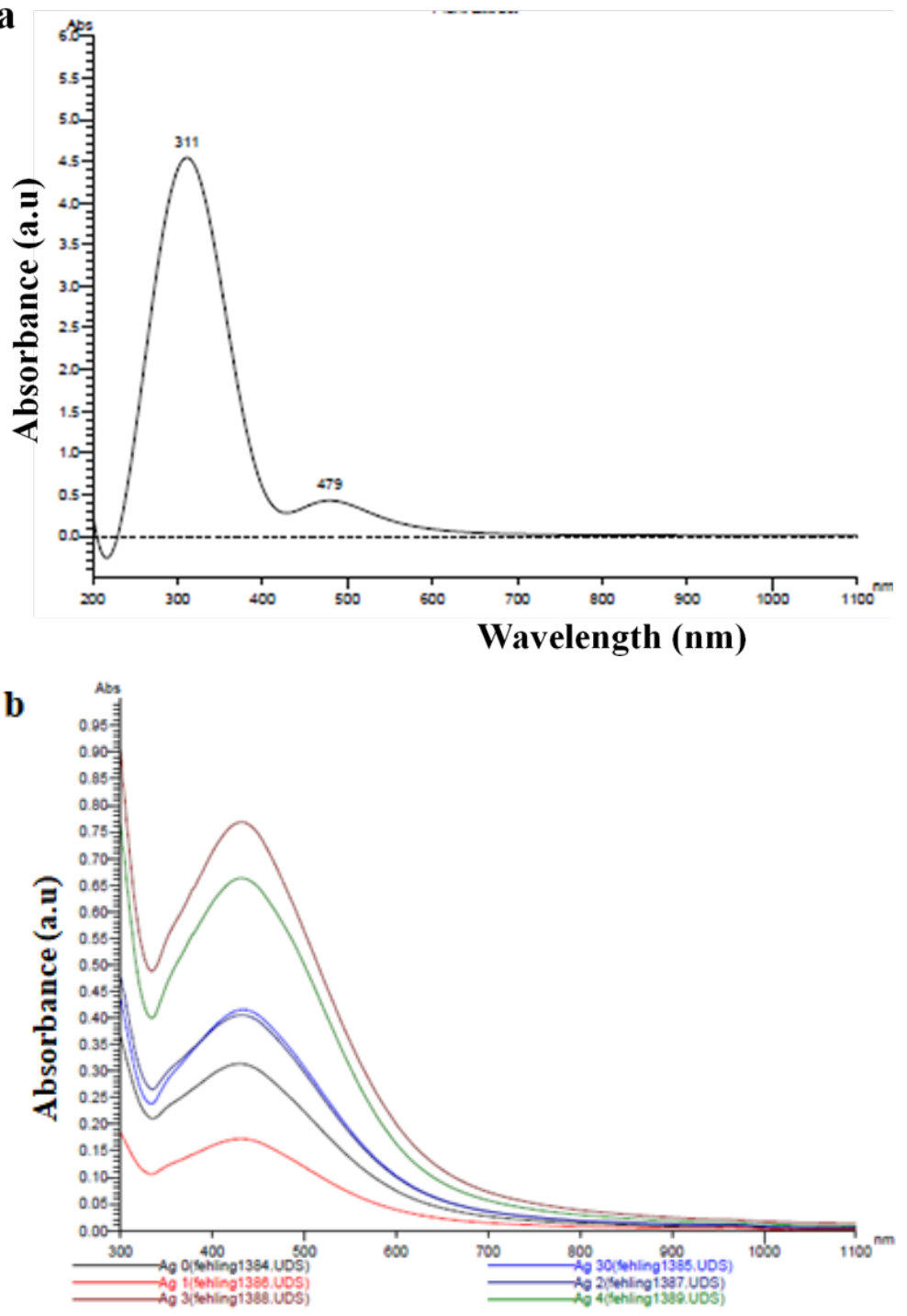

Wavelength (nm)

Fig. 4: UV-Vis spectroscopy for a.) Manilkara hexandra Stem Bark Extract b.) Synthesized Manilkara hexandra stem bark silver nanoparticles (MHSB-AgNPs) for different time intervals (Black-0 min, blue-30 min, red-1h, Dark blue-2h, Maroon-3h, Green-4h) 
Table 2: GC-MS analysis of Manilkara hexandra stem bark extract

\begin{tabular}{|c|c|c|c|c|c|c|c|}
\hline $\begin{array}{l}\text { S. } \\
\text { No. }\end{array}$ & $\begin{array}{l}\text { Retention } \\
\text { time }\end{array}$ & $\begin{array}{l}\text { Area } \\
\%\end{array}$ & $\begin{array}{l}\text { Height } \\
\%\end{array}$ & $\mathbf{A} / \mathrm{H}$ & $\begin{array}{l}\text { Molecular } \\
\text { weight }\end{array}$ & Name & Formula \\
\hline 1. & 6.360 & 1.18 & 0.81 & 7.39 & 196 & $\begin{array}{l}\text { 1H-Cyclopenta[c]furan-3(3aH)-one, 6,6a-dihydro-1-(1,3- } \\
\text { dioxolan-2-yl)-, (3aR,1-trans,6a-cis) }\end{array}$ & $\mathrm{C}_{10} \mathrm{H}_{12} \mathrm{O}_{4}$ \\
\hline 2. & 8.884 & 1.61 & 1.75 & 4.70 & 172 & Oxalic acid, cyclobutyl ethyl ester & $\mathrm{C}_{8} \mathrm{H}_{12} \mathrm{O}_{4}$ \\
\hline 3. & 9.025 & 1.76 & 1.20 & 7.47 & 116 & 4-Heptanol, Dipropylcarbinol & $\mathrm{C}_{7} \mathrm{H}_{16} \mathrm{O}$ \\
\hline 4. & 11.448 & 1.02 & 2.39 & 2.18 & 114 & 1-Hepten-4-ol & $\mathrm{C}_{7} \mathrm{H}_{14} \mathrm{O}$ \\
\hline 5. & 11.573 & 1.41 & 2.42 & 2.97 & 130 & 4-OCTANOL & $\mathrm{C}_{8} \mathrm{H}_{18} \mathrm{O}$ \\
\hline 6. & 13.617 & 1.00 & 1.21 & 4.23 & 75 & BUTYL ALCOHOL-1-D1 & $\mathrm{C}_{4} \mathrm{H}_{9} \mathrm{DO}$ \\
\hline 7. & 13.778 & 3.01 & 3.78 & 4.06 & 106 & BUTANE, 2-CHLORO-2-METHYL- & $\mathrm{C}_{5} \mathrm{H}_{11} \mathrm{Cl}$ \\
\hline 8. & 13.961 & 5.16 & 3.31 & 7.94 & 130 & ALLYL HYDRACRYLATE & $\mathrm{C}_{6} \mathrm{H}_{10} \mathrm{O}_{3}$ \\
\hline 9. & 14.081 & 3.39 & 5.94 & 2.91 & 184 & 5-(2-methylpropyl)nonane & $\mathrm{C}_{13} \mathrm{H}_{28}$ \\
\hline 10. & 14.405 & 1.92 & 4.28 & 2.29 & 230 & Propanedioic acid, oxo-, bis(2-methylpropyl) ester & $\mathrm{C}_{11} \mathrm{H}_{18} \mathrm{O}_{5}$ \\
\hline 11. & 15.167 & 1.10 & 0.48 & 11.75 & 154 & 5-METHYL-1,3,2,4-DITHIADISZOLIUM CHLORIDE & $\mathrm{C}_{2} \mathrm{H}_{3} \mathrm{ClN}_{2} \mathrm{~S}_{2}$ \\
\hline 12. & 15.399 & 1.03 & 2.51 & 2.09 & 240 & 1-IODOOCTANE & $\mathrm{C}_{8} \mathrm{H}_{17} \mathrm{I}$ \\
\hline 13. & 15.567 & 53.87 & 45.85 & 6.00 & 330 & Phthalic acid, di-(1-hexen-5-yl) ester & $\mathrm{C}_{20} \mathrm{H}_{26} \mathrm{O}_{4}$ \\
\hline 14. & 16.599 & 12.18 & 10.82 & 5.75 & 130 & 5-Methyl-1-heptanol & $\mathrm{C}_{8} \mathrm{H}_{18} \mathrm{O}$ \\
\hline 15. & 16.772 & 2.66 & 4.40 & 3.09 & 236 & Sulfurous acid, hexyl 2-pentyl ester & $\mathrm{C}_{11} \mathrm{H}_{24} \mathrm{O}_{3} \mathrm{~S}$ \\
\hline 16. & 17.453 & 1.03 & 2.18 & 2.41 & 272 & 1-(2-HYDROXYETHOXY)-PENTADECANE & $\mathrm{C}_{17} \mathrm{H}_{36} \mathrm{O}_{2}$ \\
\hline 17. & 19.764 & 1.26 & 2.21 & 2.92 & 278 & 1,2-Benzenedicarboxylic acid, Bis(2-methylpropyl) ester & $\mathrm{C}_{16} \mathrm{H}_{22} \mathrm{O}_{4}$ \\
\hline 18. & 27.143 & 2.27 & 1.67 & 6.95 & 162 & Butanoic acid, 3-chloroprop-2-enyl ester & $\mathrm{C}_{7} \mathrm{H}_{11} \mathrm{ClO}_{2}$ \\
\hline 19. & 27.292 & 1.57 & 1.32 & 6.04 & 148 & Dimethyl,tert-butoxysilanol $\$ \$$ tert-butoxy (Dimethyl) silanol & $\mathrm{C}_{6} \mathrm{H}_{16} \mathrm{O}_{2} \mathrm{Si}$ \\
\hline \multirow[t]{2}{*}{20.} & 27.346 & 1.58 & 1.47 & 5.49 & 250 & $\begin{array}{l}\text { Quinoxalin-2-one, decahydro-3-(3,3-dimethyl-2- } \\
\text { oxobutenylideno)- }\end{array}$ & $\mathrm{C}_{14} \mathrm{H}_{22} \mathrm{~N}_{2} \mathrm{O}_{2}$ \\
\hline & & 100 & 100 & & & & \\
\hline
\end{tabular}

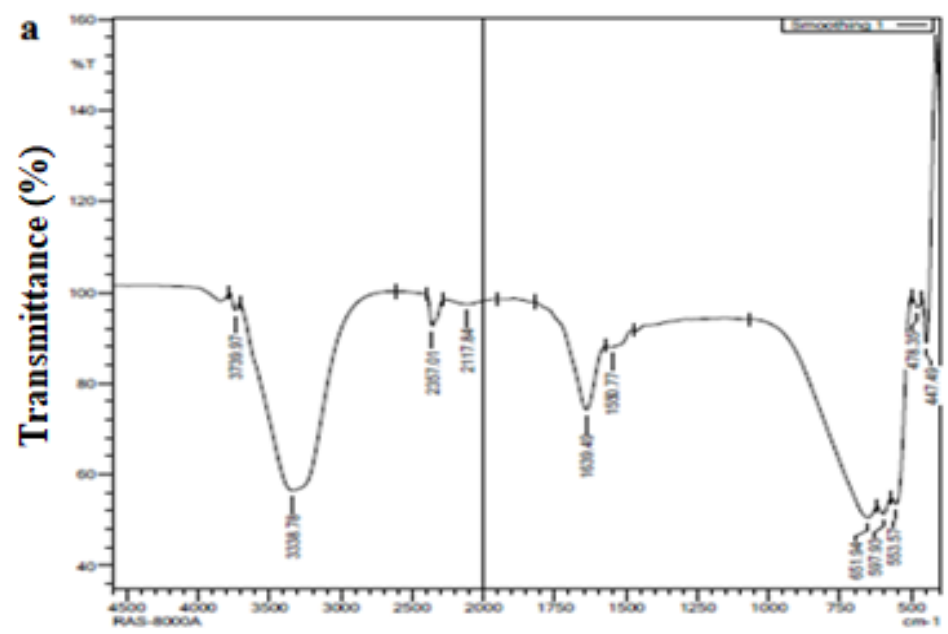

Wavenumber $\left(\mathrm{Cm}^{-1}\right)$

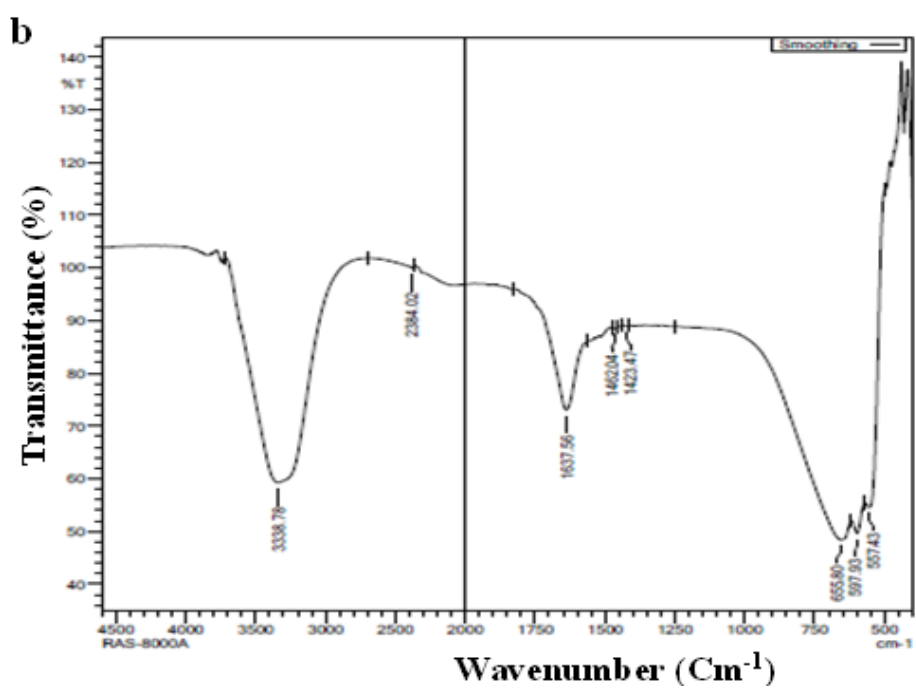

Fig. 5: Fourier transform infrared spectroscopy of a.) Manilkara hexandra aqueous stem bark extract and b.) synthesized Manilkara hexandra stem bark silver nanoparticles (MHSB-AgNPs) 
Fourier Transform Infrared spectrum of Manilkara hexandra stem bark extract shows various peaks as in fig. 5 a. The bands at $3739 \mathrm{~cm}$ 1, $3338 \mathrm{~cm}^{-1}, 2357 \mathrm{~cm}^{-1}, 2117 \mathrm{~cm}^{-1}, 1639 \mathrm{~cm}^{-1}, 1550 \mathrm{~cm}^{-1}$, and 651 $\mathrm{cm}^{-1}$ corresponds to- $\mathrm{OH}$ stretching alcohol, $\mathrm{OH}$ is stretching, $\mathrm{O}=\mathrm{C}=\mathrm{O}$ stretching carbon dioxide, $\mathrm{C} \equiv \mathrm{C}$ stretching alkyne, $\mathrm{C}=\mathrm{N}$ stretching, $\mathrm{N}$ $\mathrm{O}$ is stretching nitro compounds, $\mathrm{C}-\mathrm{Br}$ stretching halo compounds, respectively. And for Manilkara hexandra stem bark silver nanoparticles (MHSB-AgNPs), there are various peaks as in fig. $5 \mathrm{~b}$. The band at $3338 \mathrm{~cm}^{-1}, 2384 \mathrm{~cm}^{-1}, 1637 \mathrm{~cm}^{-1}, 1462 \mathrm{~cm}^{-1}, 1423 \mathrm{~cm}^{-1}$ and $655 \mathrm{~cm}^{-1}$ corresponding to- $\mathrm{OH}$ is stretching alcohol, $\mathrm{O}=\mathrm{C}=0$ stretching, $\mathrm{NH}$ is bending amine, $\mathrm{C}-\mathrm{H}$ bending alkane, $\mathrm{C}-\mathrm{H}$ bending alkane methyl group, $\mathrm{C}-\mathrm{Br}$ stretching halo compounds, respectively. Fourier Transform Infrared spectrum shows the presence of bio- molecules and metal nanoparticles present in the synthesized nanoparticles [18].

The surface morphology, shapes, size distribution in nano $\left(10^{-9}\right)$ and micro $\left(10^{-6}\right)$ scales were identified by using Field Emission scanning Electron Microscope (FE-SEM) [19]. Particles are spherical and size ranges from $15-50 \mathrm{~nm}$ as shown in fig. 6a. Energy Dispersive Spectroscopy (EDAX) shows the presence of Silver (Ag) which confirms the formation of Manilkara hexandra stem bark silver nanoparticles (MHSB-AgNPs) as shown in fig. 6b. There are also other peaks such as Carbon (C), Chlorine ( $\mathrm{Cl}$ ), Oxygen (O), Potassium $(\mathrm{K})$ they are due to biocompounds from the plant. The Silicon $(\mathrm{Si})$ is due to glass wafer used for coating the nanoparticles.

a
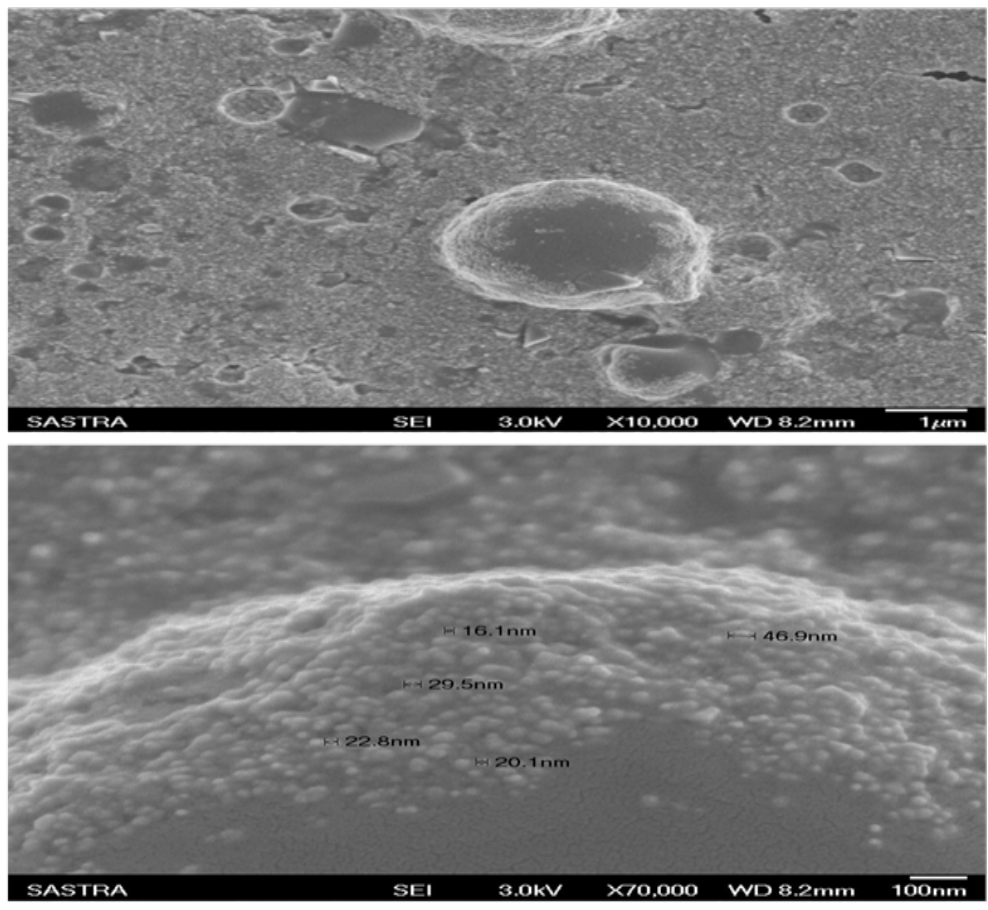

b

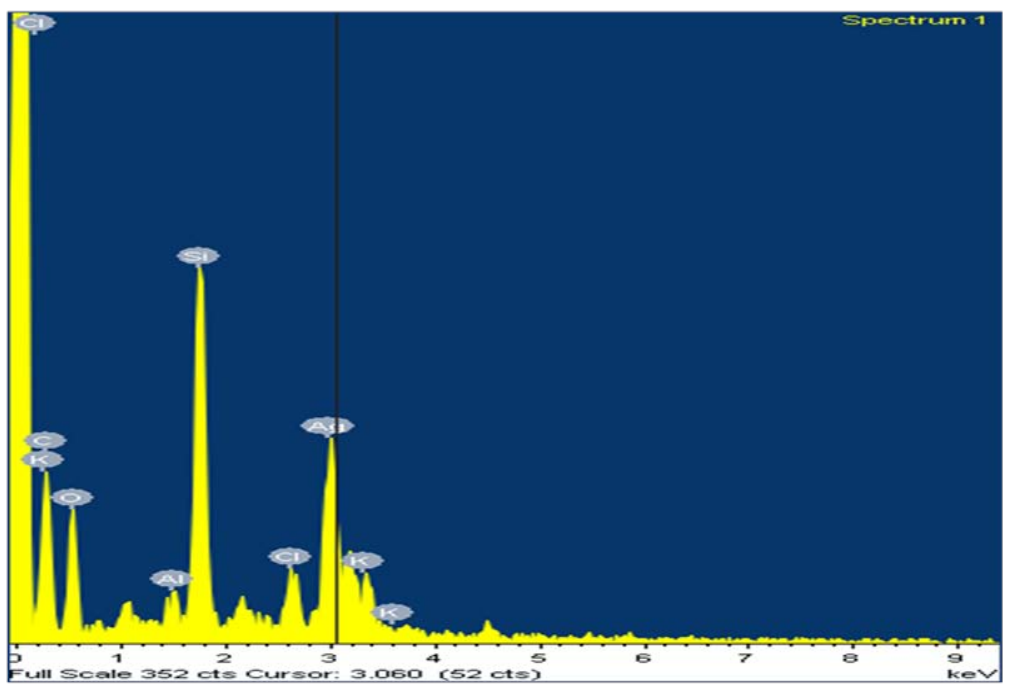

Fig. 6: a.) Field Emission Scanning Electron Microscopy (FE-SEM) image of MHSB-AgNPs and b.) Energy Dispersive Spectroscopy (EDAX) spectrum of MHSB-AgNPs

X-ray diffraction analysis (XRD) of Manilkara hexandra stem bark silver nanoparticles (MHSB-AgNPs) shows the different peaks at (111), (200), (220), (311) and is face-centered cubic (FCC). Standard data file for silver (JCPDS No. 04-0783). Bragg reflection is based on the crystal of silver nanoparticles (AgNPs). These phases were indexed to a spherical shape. The Scherrer equation was used to calculate the particle size and found to be in the range of $38 \mathrm{~nm}$ as in fig. 7. 


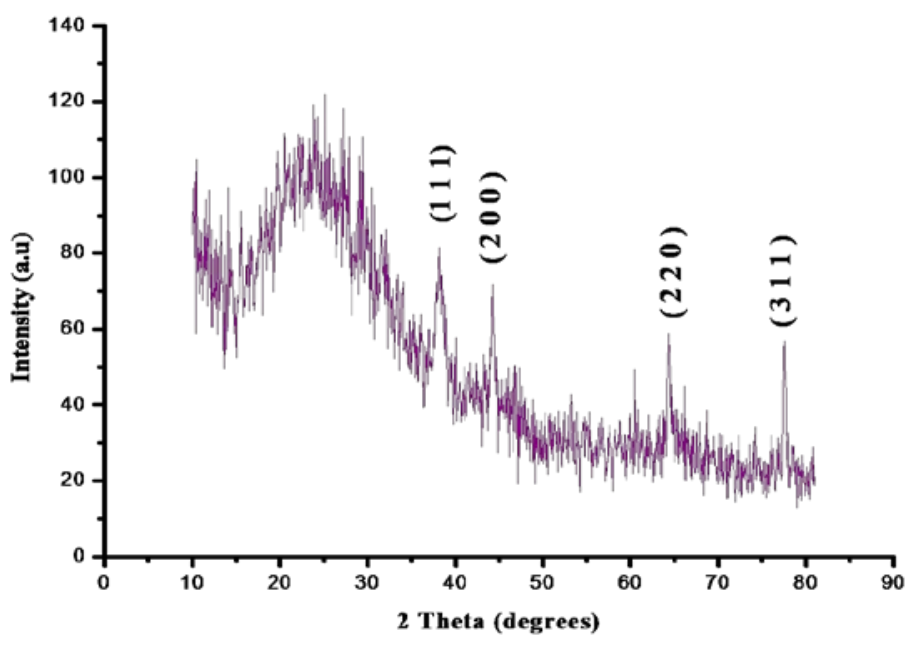

Fig. 7: X-ray powder diffraction (XRD) of MHSB-AgNPs

Dynamic light scattering (DLS) analysis shows the average size to be at $68 \mathrm{~nm}$. Dynamic light scattering (DLS) shows a minor peak at $3.7 \mathrm{~nm}$, medium peak at $16.5 \mathrm{~nm}$ and a major peak at $121 \mathrm{~nm}$ as in fig. 8a. The size of the particles is high in Dynamic light scattering (DLS) compared to Field Emission scanning Electron Microscope (FE-SEM). The Dynamic light scattering (DLS) is measured based on the hydrodynamic diameter of the particles and it provide average particle size whereas Field Emission scanning Electron Microscope (FE-SEM) is examined by dry particles [20]. The high stability of zeta potential $(-17 \mathrm{~nm})$ is confirmed from fig. $8 \mathrm{~b}$. In zeta potential, the magnitude is predictive for the stability of the nanoparticles [21].

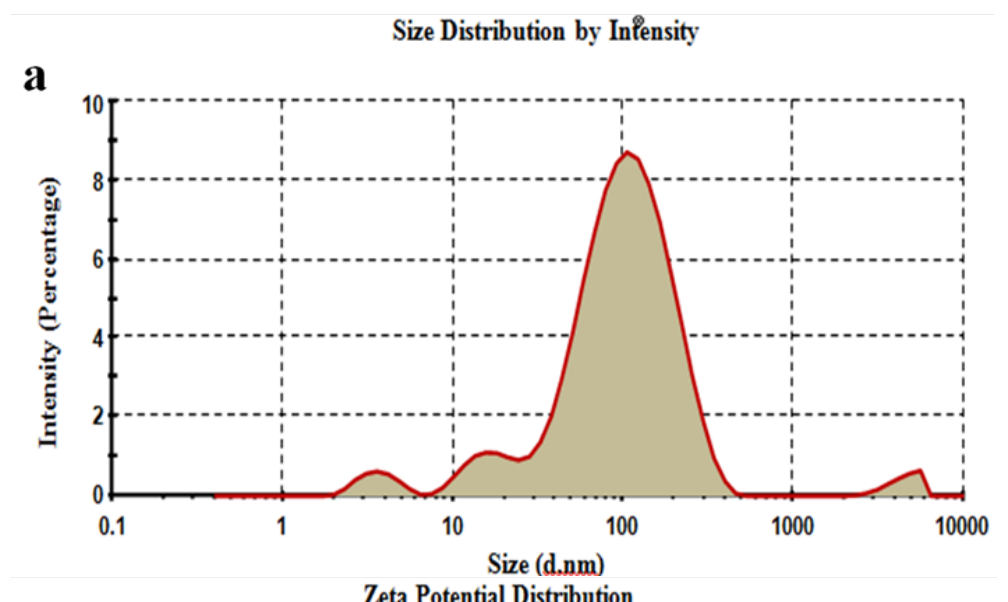

b

Zeta Potential Distribution

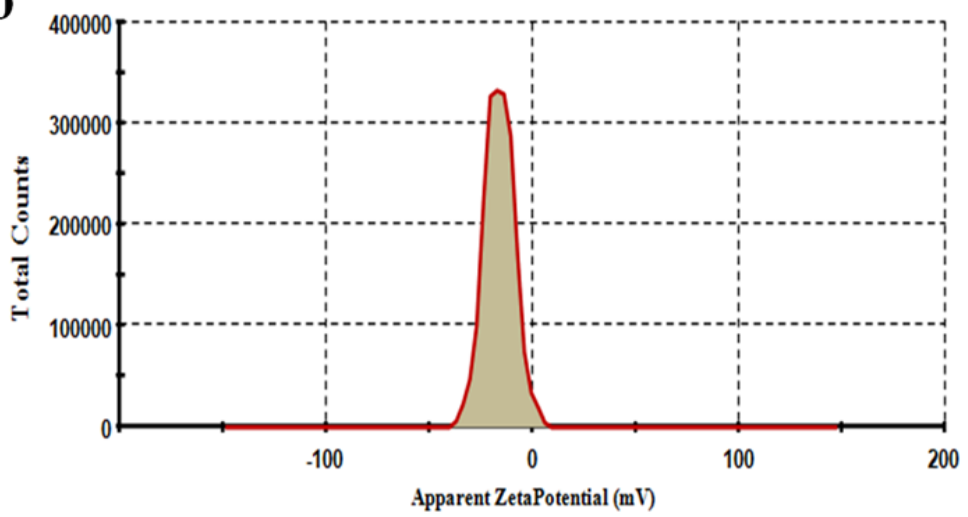

Fig. 8: a.) The hydrodynamic size of MHSB-AgNPs and b.) Zeta potential of MHSB-AgNPs

The thermal stability of Manilkara hexandra stem bark silver nanoparticles (MHSB-AgNPs) was analyzed using Thermogravimetry/Differential Thermal Analysis (TG/DTA). In TG curve, we observe weight loss from $4.4340 \mathrm{mg}$ to $2.806 \mathrm{mg}$ from room temperature to $820 \mathrm{C}$ and the residue is $63.29 \%$ after $820^{\circ} \mathrm{C}$ it is constant there is no weight loss. The weight was lost at three 
stages from room temperature to $130 \mathrm{C}, 130^{\circ} \mathrm{C}$ to $450^{\circ} \mathrm{C}$ and $450^{\circ} \mathrm{C}$ to $820^{\circ} \mathrm{C}$. The primary weight loss is due to the moisture content present in the nanoparticles. The major weight loss is at $1^{\circ} \mathrm{B}$.0to $450^{\circ} \mathrm{C}$ it is due to decomposition of materials and is shown in fig. 9. The Differential Thermal Analysis (DTA) reveals two exothermic peak at $120^{\circ} \mathrm{C}$ and $300^{\circ} \mathrm{C}$. The peak at $300^{\circ} \mathrm{C}$ shows the melting point of silver nanoparticles. The release of energy atC3i0 depicted in DTA curve shown in fig. The crystallinity and thermal decomposition can be examined for silver nanoparticles in DTA [22].

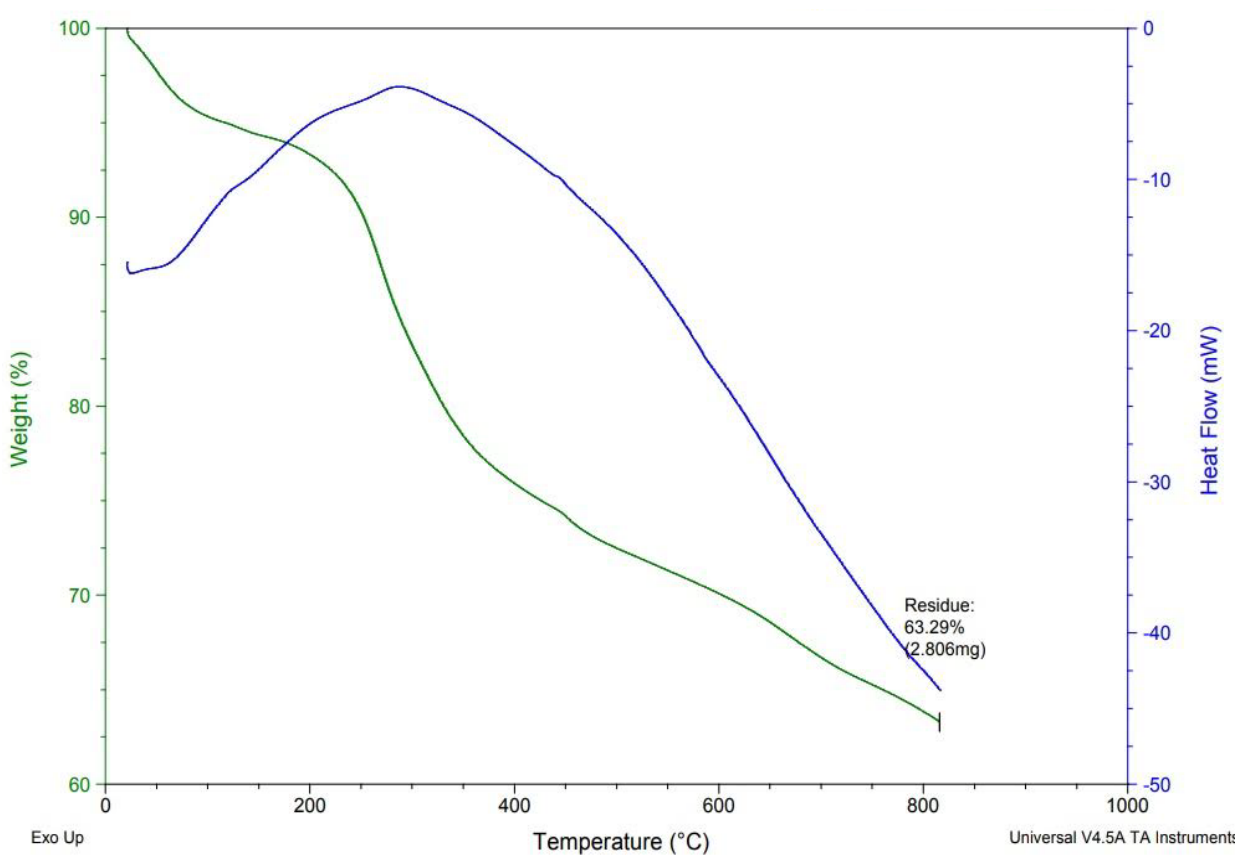

Fig. 9: Thermogravimetry/Differential Thermal Analysis (TG/DTA) of MHSB-AgNPs

We observe three exothermic peaks at $35^{\circ} \mathrm{C}, 192.3^{\circ} \mathrm{C}, 315^{\circ} \mathrm{C}$ and four endothermic peak at $57.1 \mathrm{C}, 135^{\circ} \mathrm{C}, 290^{\circ} \mathrm{C}$ and $312^{\circ} \mathrm{C}$. The nanoparticles melt in an exothermic peak at $315 \mathrm{C}$. This stage is called as melting stage and the energy is been released by the material at this stage. The nanoparticles are stable until $315 \mathrm{c}$.
There are also small endothermic and exothermic peaks present in the Differential Scanning Calorimetry (DSC) curve. There are also peaks present in glass transition stage and crystalline stage. These peaks are due to change properties of nanoparticles shown in fig. 10 .

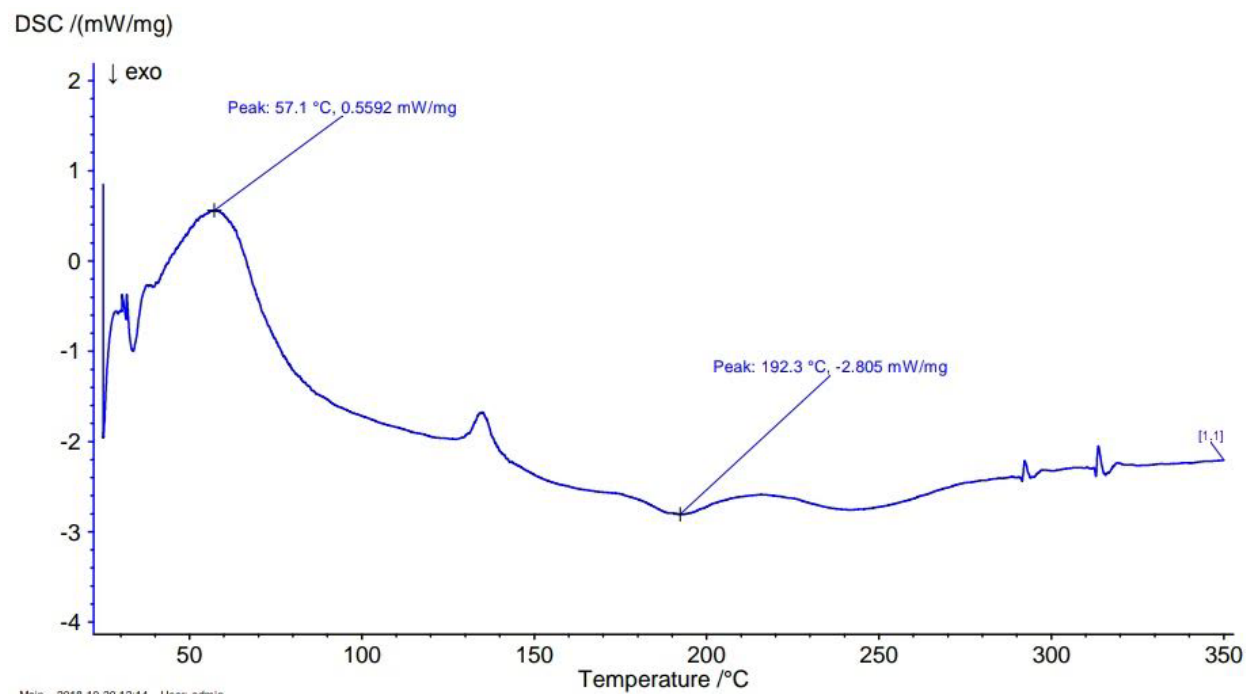

Fig. 10: Differential scanning calorimetry (DSC) of MHSB-AgNPs

\section{Antimicrobial assay}

The bio-synthesized Manilkara hexandra stem bark silver nanoparticles (MHSB-AgNPs), stem bark extract, silver nitrate $\left(\mathrm{AgNO}_{3}\right)$ solution, and standards were subjected to bacterial assays. Five different bacteria were analyzed they are Klebsiella pneumonia, Staphylococcus aureus, Escherichia coli, Pseudomonas aeruginosa and Streptococcus pneumonia among these Manilkara hexandra stem bark silver nanoparticles (MHSB-AgNPs) have high Zone of Inhibition (ZOI) for Klebsiella pneumoniae and Escherichia coli at $11.5 \mathrm{~mm}$ as in fig. 11. There is no ZOI for the silver nitrate $\left(\mathrm{AgNO}_{3}\right)$ solution and a stem bark extract. This explains that the stem bark extract is non-toxic and adaptable to nature as shown in table 3. 


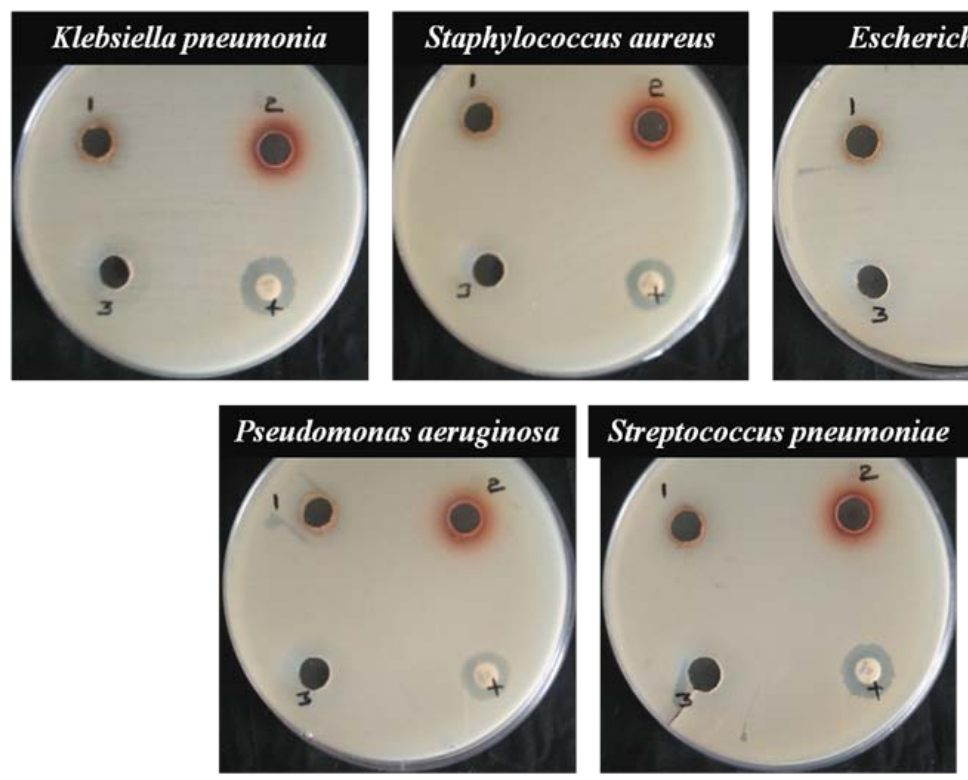

Fig. 11: Antibacterial activity of stem bark extract, MHSB-AgNPs, AgNO ${ }_{3}$ and Standard were examined using the well diffusion method

Table. 3: Antibacterial activity of stem bark Extract, MHSB-AgNPs, $\mathrm{AgNO}_{3}$, and standard were examined using the well diffusion method

\begin{tabular}{|c|c|c|c|c|c|}
\hline \multirow[b]{2}{*}{ S. No. } & \multirow[b]{2}{*}{ Name of the organism } & \multicolumn{4}{|c|}{ Zone of inhibition in $\mathrm{mm}(75 \mu \mathrm{l} / \mathrm{ml})^{*}$} \\
\hline & & Stem bark extract (1) & MHSB-AgNPs (2) & $\mathrm{AgNO}_{3}$ solution (3) & Amoxicillin (4) \\
\hline 1. & Klebsiella pneumoniae & - & $11.48 \pm 0.758$ & - & $14.20 \pm 0.060$ \\
\hline 2. & Staphylococcus aureus & - & $11.17 \pm 0.023$ & - & $12.17 \pm 0.263$ \\
\hline 3. & Escherichia coli & - & $11.42 \pm 0.011$ & - & $14.20 \pm 0.033$ \\
\hline 4. & Pseudomonas aeruginosa & - & $10.17 \pm 0.043$ & - & $12.15 \pm 0.033$ \\
\hline 5. & Streptococcus pneumoniae & - & $11.20 \pm 0.040$ & - & $13.17 \pm 0.031$ \\
\hline
\end{tabular}

${ }^{*}$ All the experiments were repeated independently three times and the values were represented as an average means \pm Standard deviation.

They are also examined for a fungal pathogen such as Candida albicans and Aspergillus niger and it show good inhibition for Manilkara hexandra stem bark silver nanoparticles (MHSB-AgNPs) Aspergillus niger $(5.18 \pm 0.026 \mathrm{~mm})$ and light inhibition of Candida albicans $(3.13 \pm 0.016 \mathrm{~mm})$. There is a small inhibition for stem bark extract shown for Aspergillus niger $(2.18 \pm 0.031 \mathrm{~mm})$ and no inhibition of Candida albicans. The Fluconazole is used as standard and its inhibition is $8 \mathrm{~mm}$ for both fungal strains and there is also no inhibition for silver nitrate $\left(\mathrm{AgNO}_{3}\right)$ solution as shown in fig. 12 and table 4 .
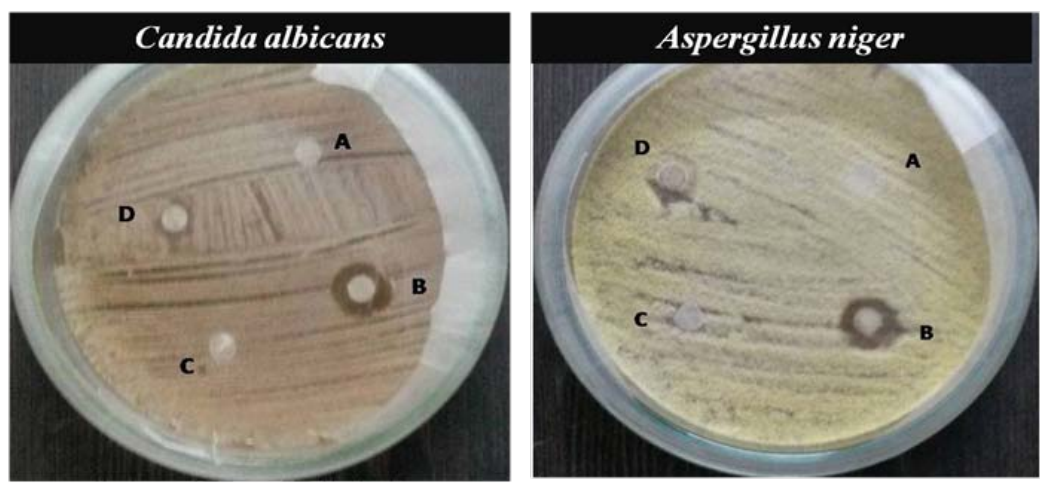

Fig. 12: Antifungal activity of stem bark extract, MHSB-AgNPs, $\mathrm{AgNO}_{3}$ and standard were examined using the disk diffusion method

Table 4: Antifungal activity of stem bark extract, MHSB-AgNPs, $\mathrm{AgNO}_{3}$, and standard were examined using the disk diffusion method

\begin{tabular}{|c|c|c|c|c|c|}
\hline \multirow[t]{2}{*}{ S. No. } & \multirow[t]{2}{*}{ Name of the organism } & \multicolumn{4}{|c|}{ Zone of inhibition in $\mathrm{mm}(10 \mu \mathrm{l})^{*}$} \\
\hline & & Stem bark extract (C) & MHSB-AgNPs (D) & $\mathrm{AgNO}_{3}$ solution (A) & Fluconazole (B) \\
\hline 1. & Candida albicans & - & $3.13 \pm 0.016$ & - & $8.17 \pm 0.031$ \\
\hline 2. & Aspergillus niger & $2.18 \pm 0.031$ & $5.18 \pm 0.026$ & - & $8.27 \pm 0.036$ \\
\hline
\end{tabular}

*All the experiments were repeated independently three times and the values were represented as an average means \pm Standard deviation. 


\section{Antioxidant assay (in vitro DPPH method)}

The free radical scavenging activity in vitro is examined for various concentrations of Manilkara hexandra stem bark silver nanoparticles (MHSB-AgNPs) from $20 \mu \mathrm{g} / \mathrm{ml}$ to $100 \mu \mathrm{g} / \mathrm{ml}$. They are alternatively compared with ascorbic acid, which is a standard for antioxidant assay. Here Manilkara hexandra stem bark silver nanoparticles (MHSB-AgNPs) show a good antioxidant property but low compared with the ascorbic acid standard. But, Manilkara hexandra stem bark silver nanoparticles (MHSB-AgNPs) is non-toxic and has no side effect when compared with ascorbic acid. The $\mathrm{IC}_{50}$ value is calculated as in fig. 13 . and table 5 .

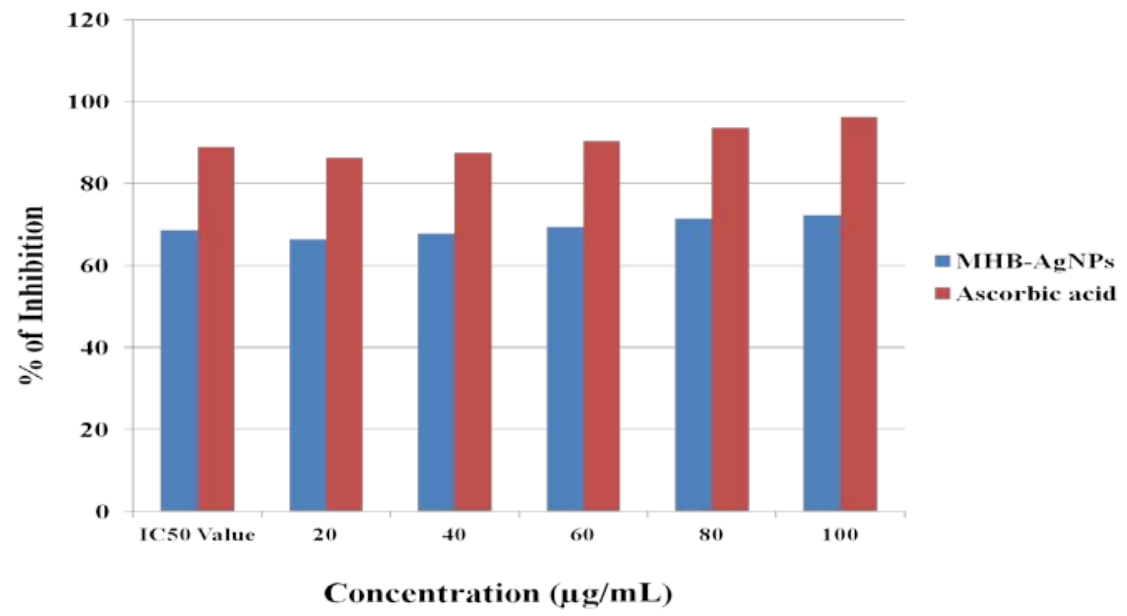

Fig. 13: DPPH free radical scavenging assay of MHSB-AgNPs were compared with the standard measurements were done in triplicates $(n=3$, mean $\pm S D)$ in a bar chart

Table 5: Free radical scavenging activities (DPPH method in vitro) of MHSB-silver nanoparticles and standard were triplicated

\begin{tabular}{lll}
\hline Concentration of silver nanoparticles $(\boldsymbol{\mu g} / \mathbf{m l})$ & MHSB-AgNPs & Ascorbic acid \\
\hline 20 & $66.53 \pm 0.006$ \\
40 & $67.74 \pm 0.003$ \\
60 & $69.43 \pm 0.007$ \\
80 & $71.54 \pm 0.006$ \\
100 & $72.38 \pm 0.020$ \\
\hline
\end{tabular}

\section{DISCUSSION}

It is stated that active bio-compounds present in dried materials are more concentrated than that of fresh materials [23, 24]. Here silver nanoparticles were synthesized by using Manilkara hexandra stem bark extract belong to the family of sapotaceae. The change of color from yellow to dark brown was observed. Which is similar to the results of previous studies Adhatoda vasica leaf extract [25]. In Aegle maremelos leaf extract silver nanoparticle shows the spectral studies close to $450 \mathrm{~nm}$ this confirms the formation of silver nanoparticles and this absorption depends on the dielectric medium, particle size and chemical surrounding [26] which corresponds to the formation of AgNPs (430-440 nm) from Manilkara hexandra stem bark. The DLS report of MHSB-AgNPs (68 nm) correlate with the Lantana camara flower extract for silver nanoparticles was $62.8 \mathrm{~nm}$ [27]. The long term stability of AgNPs can be examined by zeta potential [28, 29]. In general, the stability of zeta potential which is negatively charged surfaces to prevent the aggregation of nanoparticles and also control the size and shapes of silver nanoparticles [30]. The Caralluma umbellate silver nanoparticles the particle size is examined by SEM which is in the range $50 \mathrm{~nm}$ to $85 \mathrm{~nm}$ [31]. This corresponds to the size of MHSB-AgNPs this shows the silver nanoparticles is synthesized in a proper method. Antimicrobial report of silver nanoparticle was not clear. Due to the three different mechanisms of action, first silver ions attached to the bacterial cell membrane and cause plasmolysis (bacterial cell wall is separated from the cytoplasm of bacteria), this inhibit synthesis of bacterial cell membrane [32]. Secondly, silver nanoparticles combined with S (sulphur) and P (phosphorus) contains compounds which present inside and outside of the bacterial cell, this affect respiratory chain reaction, cell division and finally, it leads to cell death [33]. Finally, $\mathrm{Ag}$ ions were released from silver nanoparticles and this penetrate into the cell wall, this cause the condensation of DNA damage and also affect protein synthesis [34]. Overall, results show the involvements of all these three phenomena of synthesized particle cause the killing of pathogens. Antioxidant agents are that which restricts the deleterious effect of oxidant reactions. This restriction involves preventing the radical formation or scavenging free radicals and thereby can enhance the immune defense and lower the possibility of diseases occurrence [35]. In our present study, we use the DPPH method of free radical scavenging activity. The percentage of inhibition increases with increases in the concentration of silver nanoparticles. This shows that silver nanoparticles may donate electrons to DPPH and a lipophilic radical accept that electron thereby conversion of color from purple to yellow is detected [36].

\section{CONCLUSION}

The present work focused on the synthesis of silver nanoparticles using the stem bark of Manilkara hexandra. The silver nanoparticles is then characterized by various techniques such as UV-vis, FT-IR, FESEM, EDAX, XRD, DLS, Zeta potential, TG/DTA, DSC. The GC-MS analysis, project 20 bio-compounds for aqueous stem bark extract and are also evaluated by phytochemical screening. These biocompounds play important role to synthesize the nanoparticles after it is validated by various microbial pathogens. They are indulged in antioxidant assay in vitro and nanoparticles show good report for microbial pathogen and antioxidant assay. The particle size is $15-50 \mathrm{~nm}$. Here we eventually say that this method is simple, eco-friendly, and is a natural method. This can be implied in the drug production.

\section{AUTHORS CONTRIBUTIONS}

All the author have contributed equally

\section{CONFLICTS OF INTERESTS}

Declared none 


\section{REFERENCES}

1. Valiathan MS. Healing plants. Curr Sci 1998;75:1122-6.

2. Robinson MM, Zhang X. Traditional medicines: global situation, issues and challenges, the world medicines situation. 3rd ed. World Health Organization, Geneva; 2011.

3. Alexander JW. History of the medical use of silver. Surg Infect 2009;10:289-92.

4. Rai M, Yadav A. Plants as potential synthesiser of precious metal nanoparticles: progress and prospects. IET Nanobiotechnol 2013;7:117-24.

5. Anuradha G, Syama Sundar B, Ramana MV, Sreekanth Kumar J, Sujatha T. Single-step synthesis and characterization of silver nanoparticles from Ocimum tenuiflorum L. green and purple. IOSR J Appl Chem 2014;7:123-7.

6. Jayapriya E, Lalitha P. Synthesis of silver nanoparticles using leaf aqueous extract of Ocimum basilicum (L.). Int J Chem Tech Res 2013;5:2985-92.

7. Patra JK, Baek KH. Green nanobiotechnology: factors affecting synthesis and characterization techniques. J Nanomat 2014;2014:1-12.

8. Eby DM, Luckarift HR, Johnson GR. Hybrid antimicrobial enzyme and silver nanoparticles coatings for medical instruments. ACS Appl Mater Interfaces 2009;1:1553-60.

9. Narayanan KB, Sakthivel N. Green synthesis of biogenic metal nanoparticles by terrestrial and aquatic phototrophic and heterotrophic eukaryotes and biocompatible agents. Adv Colloid Interface Sci 2011;169:59-79.

10. Irudaya Monisha S, Jeyaleela GD, Immaculate AA, Vimala JR. Comparative studies on yield and the phytochemical appraisal (Quality and Quantity) of Manilkara hexandra (Roxb) dubard using leaf, stem, and bark. J Pharmacogn Phytother 2017;6:2052-8.

11. Tripathi V, Tabor SL, Mantica PF, Utsuno Y, Bender P, Cook J, et al. Physical Rev Lett 2010;104:129202.

12. Menon S, Agarwal H, Kumar RS, Venkat Kumar S. Green synthesis of silver nanoparticles using medicinal plant Acalypha indica leaf extracts and its application as an antioxidant and antimicrobial agent against foodborne pathogens. Int J Appl Pharm 2017;9:42-50.

13. Harborne JB. Textbook of phytochemical methods. 1st ed. London: Chapman and Hall; 1973.

14. Wright GD. Resisting resistance: new chemical strategies for battling superbugs. Chem Biol 2000;7:R127-32.

15. Bhattacharya D, Rajinder G. Nanotechnology and potential of microorganisms. Crit Rev Biotechnol 2005;25:199-204.

16. Mohamed S Abdel Aziz, Mohamed S Shaheen, Aziza A ElNekeety, Mosaad A Abdel Wahhab. Antioxidant and antibacterial activity of silver nanoparticles biosynthesized using Chenopodium murale leaf extract. J Saudi Chem Soc 2014;18:356-63.

17. Anthony E, Sathiavelu M, Arunachalam S. Synthesis of silver nanoparticles from the medicinal plant Bauhinia acuminata and Biophytum sensitivum a compartitive study of its biological activities with plant extract. Int J Appl Pharm 2017;9:22-9.

18. Marie Isabelle Baraton. Surface analysis of semiconducting nanoparticles by FTIR spectroscopy, nanocrystalline metals and oxides, springer, boston, MA; 2002. p. 165-87.

19. Shameli K, Ahmad MB, Al-Mulla EAJ, Ibrahim NA, Shabanzadeh $P$, Rustaiyan A, et al. Green biosynthesis of silver nanoparticles using callicarpa maingayi stem bark extraction. Molecules 2012;17:8506-17.

20. Ahmad N, Sharma S, Alam MK, Singh VN, Shamsi SF, Mehta BR, et al. Rapid synthesis of silver nanoparticles using dried medicinal plant of basil. Colloids Surf B 2010;81:81-6.

21. Zhang Y, Kohler N, Zhang M. Surface modification of superparamagnetic magnetite nanoparticles and their intracellular uptake. Biomaterials 2002;23:1553-61.

22. Khan MAM, Kumar S, Ahamed M, Alrokayan SA, AlSalhi MS. Structural and thermal studies of silver nanoparticles and electrical transport study of their thin films. Nanoscale Res Lett 2011;6:434.

23. Romero CD, Chopin SF, Buck G, Martinez E, Garcia M, Bixby L. Antibacterial properties of common herbal remedies of the southwest. J Ethnopharmacol 2005;99:253-7.

24. Farukh A, Ahmad I, Mehmood Z. Antioxidant and free radical scavenging properties of twelve traditionally used Indian medicinal plants. Turkish J Biol 2006;30:177-83.

25. Bhumi G, Rao G, Savithramma N. Green synthesis of silver nanoparticles from the leaf extract of Adhatoda vasica nees and assessment of its antibacterial activity. Asian J Pharm Clin Res 2015;8:42-50.

26. Patel S, Sivaraj R, Rajiv P, Venckatesh R, Seenivasan R. Green synthesis of silver nanoparticles from the leaf extract of Aegle marmelos and evaluation of its antibacterial activity. Int J Pharm Pharm Sci 2015;7:169-73.

27. Fatimah Is, Indrani N. Silver nanoparticles synthesized using Lantana camara flower extract by reflux, microwave and ultrasound methods. Chem J Moldova 2018;13:1857-27.

28. Shabanzadeh P, Yusof R, Shameli K. Artificial neural network for modeling the size of silver nanoparticles' prepared in montmorillonite/starch bionanocomposites. J Industrial Eng Chem 2015;24:42-50.

29. Valodkar M, Nagar PS, Jadeja RN, Thounaojam MC, Devkar RV, Thakore S. Euphorbiaceae latex-induced green synthesis of noncytotoxic metallic nanoparticle solutions: a rational approach to antimicrobial applications. Colloids Surf A 2011;384:337-44.

30. Haqq SM, Pandey H, Gerard M, Chattree A. Bio-fabrication of silver nanoparticles using Chrysanthemum coronarium flower extract and It's in vitro antibacterial activity. Int J Appl Pharm 2018;10:209-13.

31. Anju K, Jegadeeshwari AL, Gandhi NN. Optimization of green synthesized silver nanoparticles from Caralluma umbellata. Int J Appl Pharm 2018;10:103-10.

32. Morones JR, Elechiguerra JL, Camacho A, Holt K, Kouri BJ, Ramrez JT, et al. The bactericidal effect of silver nanoparticles. Nanotechnology 2005;16:2346-53.

33. Song HY, Ko KK, Oh IH, Lee BT. Fabrication of silver nanoparticles and their antimicrobial mechanisms. Eur Cells Mater 2006;11:58.

34. Feng QL, Wu J, Chen GQ, Cui FZ, Kim TN, Kim JO. A mechanistic study of the antibacterial effect of silver ions on Escherichia coli and Staphylococcus aureus. J Biomed Mater Res 2000;52:662-8.

35. Wu D, Cederbaum AI. Alcohol,oxidative stress, and free radical damage. Alcohol Res Health 2003;27:277-84.

36. Priya RS, Geetha D, Ramesh PS. Antioxidant activity of chemically synthesized AgNPs and biosynthesized Pongamia pinnata leaf extract mediated AgNPs a comparative study. Ecotoxicol Environ Saf 2016;134:308-18. 